\title{
Ophthalmic Sites Cancer TNM Finding v7
}

National Cancer Institute

\section{Source}

National Cancer Institute. Ophthalmic Sites Cancer TNM Finding v7. NCI Thesaurus.

Code C88556.

A finding about one or more characteristics of ophthalmic sites cancer, following the rules of the TNM AJCC V7 classification system. 